\title{
Relationship between Stock Market Development and Economic Growth: Evidences from Canada and Australia
}

\author{
Hung T. Nguyen ${ }^{1} \&$ Hang V. D. Pham ${ }^{2}$ \\ ${ }^{1}$ School of Economics and Finance, Massey University, Auckland, New Zealand \\ 2 Sobey School of Business, Saint Mary's University, Nova Scotia, Canada \\ Correspondence: Hung T. Nguyen, School of Economics and Finance, Massey University, Albany, Auckland, \\ New Zealand. Tel: 64-223-893-900. E-mail: nguyenthehung@neu.edu.vn
}

Received: April 1, 2014

Accepted: April 16, 2014

Online Published: June 25, 2014

doi:10.5539/ijef.v6n7p1

URL: http://dx.doi.org/10.5539/ijef.v6n7p1

\begin{abstract}
This paper examines the causality relationship between stock market development and economic growth in Canada and Australia based on the time series data for the period of 1981 Q3 to 2012 Q3. The results of Granger causality test suggest the causality between stock market development and economic growth in Canada but it is not the case in Australia. The results indicate that stock market and economic growth has long-run relationship and that the stock market development does help improve the future growth in some developed countries.
\end{abstract}

Keywords: granger causality, stock market development, economic growth

\section{Introduction}

The link between stock market development and economic growth becomes the boundless source of aspiration for researchers since the beginning of the capital market. A number of researches had been conducted and different findings were seen in different markets and investigated periods. Those who support the positive correlation between stock market and economic growth argue that when stock market rises, investors have the motivation to spend more because they feel wealthier, so the economy expands. On the other side, if the stock prices go down, investors tend to spend less, so the economic growth decreases (Pasquale, 2006). Mian, Muhammad and Usman (2008) pointed out that the stock market could be regarded as a good measure to forecast future growth and explain some applications of financial literatures. Levine and Zervos (1996), in their research on the linkages between stock markets and long-run economic growth using 41 countries from 1976 to 1993, provided evidences that stock market is positively and significantly correlated to future economic growth and capital accumulation. On the other hands, critics to these findings based their arguments on the evidences that positive correlation between stock market and economic growth could be easily captured in some emerging countries which are characterized by their boom stock markets and catching-up growths, but when it comes to developed countries, hardly does this relationship exist. Moreover, Pearce (1983) and Campbell (1989) pointed out that the stock market had generated false signals to economic movements in previous periods and hence more evidence should be taken into account to assess this relationship.

Among empirical investigations of the roles of capital market on economic growth, only few studies had addressed the causality between stock market and economic growth (Randall, Jan, \& Nauro, 1999). Causality relationship between economic growth and stock market development in some European countries were successfully investigated thank to the research of Ake Boubakari and Dehuan Jin (2010). For other developed countries, say, Canada or Australia, the question of whether or not this causality relationship exists is still in doubt. In this paper, the issue of causality relationship between stock market and economic growth in Canada and Australia will be addressed by conducting Granger causality test and the Augmented Dicky-Fuller (ADF) test based on the time series data for the period of 1981: Q3 to 2012: Q3.

The rest of this paper is structured as follow. Section 2 discusses the literature review and provides a brief introduction of two investigated markets. In Section 3, overview of the methodology and description of data is presented. Section 4 reports the results of empirical analysis relationship in the period of 1981 to 2012. Section 5 concludes the paper and reports some research limitations. 


\section{Theoretical and Empirical Overview}

\subsection{Literature Review}

A number of previous studies had been conducted to examine the relationship between stock market development and economic growth. Theoretical literatures offer different views about the role of stock market and banking sector in boosting economic growth. Stiglitz and Weiss (1981) emphasized the role of the banking sector as the only organized capital market but neglected the role of stock markets in economic growth. On the other hands, Rousseau and Wachtel (2000) and Beck and Levine (2003) showed strong evidences that not only banking sector but also stock market development are critical determinants in the growth regression. To support the roles of stock market in economic growth, Greenwood and Jovanovic (1990) and Levine (1993) pointed out that the new stock markets can increase the investors' risk adjusted returns by providing accurate information about the whole market or specific firms to investors. The efficient capital markets allowed investors to make optimal investment decisions, leading to better allocation of corporation funds. As a result, a higher rate of economic growth can be achieved (Stiglitz \& Weiss, 1981). Mirakhor and Lillanueva (1990) also shared the point that stock market plays an essential function in allocating funds to the corporate sector, which has a real effect on the economic growth. This function could be observed obviously in many developing countries where debt financing is unreachable and banks tend to give loans to a specific group of companies. Another function of stock market worth mentioning is global risk diversification. Levine (1991) highlighted that the well-developed stock market help reduce investment risks by offering opportunities for portfolio diversification. Obstfeld (1994a; b) pointed out that despite the drawback of increasing the investor's risk, more options in stock market are provided to investors to do diversified investment internationally.

Atje and Jovanic (1993) conducted cross-sectional regressions to figure out that stock markets have long-run effects on economic growth. Levine and Zervos (1996), in their research on the linkages between stock markets and long-run economic growth using 41 countries from 1976 to 1993, provided evidences that stock market is significantly correlated to current and future rates of economic growth, capital accumulation and productivity improvements. In an effort to explore the roles of stock market in economic growth in some emerging countries, Mauro (2000) found that the stock markets influence growth through a number of factors, such as market liquidity, information efficiency, corporate governance, risk diversification and savings mobilization. Similarly, Beck and Levine (2003) provided an empirical evidence to support that stock market development is strongly correlated with growth rates of real GDP per capita and plays important role in allocating capital. From different approaches, Choong et al. (1996) found that the combination of stock market opens policies and sustainable macroeconomic factors stimulate economic growth. Indeed, the well-organized stock markets provide chances to investors to make rational decisions, such as efficient capital allocation, mobilization domestic savings and diversification risks, which significantly accelerate economic growth (Caporale et al., 2004). This is also confirmed by Greenwood and Smith (1994) through their research which concluded that the large and developed stock markets can reduce cost of mobilizing savings. Recently, causality relationship between economic growth and stock market development in some European countries were successfully proved thanks to the research of Ake Boubakari and Dehuan Jin (2010).

Existing studies have mainly looked at the relation between stock market development and economic performance by using a linear regression model or clarified the causal relations between the stock market development indicators and macroeconomic variables by using such approaches as Granger causality, vector error correction modeling (VECM) or vector autoregressive modelling (VAR) (Mansor, 2011). These models were widely applied in varied research thanks to their powerfulness to address the correlation between examined variables (Levine \& Zervos, 1996a, b; Mian, Muhammad, \& Usman, 2008; Ake \& Dehuan, 2010). A number of previous studies have used Granger causality to examine the link between financial markets and growth. Thornton (1995) analyzed 22 developing economies and found empirical evidences that financial deepening promoted growth. Neusser and Kugler (1998) reported that financial sector GDP Granger-caused manufacturing sector GDP in a sample of thirteen OECD countries. Randall, Jan and Nauro (1999), by applying Granger causality test for a sample of 69 countries with varying economic conditions and levels of stock market activity, proved that there is a strong relationship between stock market activity and future economic growth for the low and lower middle income countries but it is not the case in higher income countries with more developed alternative financial mechanisms.

Recently, Anson Wong and Xianbo Zhou (2011), by applying the modified model that was firstly suggested by Levine and Zervos (1996) in 5 selected countries (China, USA, United Kingdom, Japan and Hong Kong) over the period of 1988-2008 successfully proved that the stock market development has independently a strong positive correlation with industrial production and as a result, the stock market development is one of the key 
drivers of economic growth in five examined countries. The main advantages of the new modified model proposed by Anson Wong and Xianbo Zhou (2011) lie in its simplicity and easiness to apply in varied countries and research periods. One foreseen drawback remains in its powerfulness in detecting the causality between study variables. In section 3, the methodology employed in this paper will be presented in more details.

\subsection{Stock Markets in Canada and Australia}

Toronto Stock Exchange (TSX), the largest stock exchange in Canada and among top largest in the world by market capitalization, officially came into operation since 1861 . Through a realignment plan, TSX became the Canada's sole exchange for the trading of senior equities. Over 150 years, TSX has successfully provided access to equity capital to issuers thanks to its liquid trading environment and expertise in listing procedure. As of August 2012, 1.577 companies with a combined market capitalization of CAD \$1.989.562.971.807 were listed in the stock exchange. An illustration of market capitalization of all listed companies and total value of traded stocks as the percentage of GDP in Canada from 1988 to 2012 is presented in Figure 1. During this period, two figures witnessed a relatively similar trend with their peaks captured in 2007 and 2008 respectively, followed by a sharp reduction due to the financial crisis before undergoing a recovery few years later.

The Australian Securities Exchange (ASX), created by the merger of the Australian Stock Exchange and the Sydney Futures Exchange in July 2006, has an average daily turnover of $\$ 4.685$ billion and a market capitalization of around AUD \$1.4 trillion, making it the 8th largest listed exchange group in the world and the 2nd largest in Asia-Pacific. With average daily secondary trading of over AUD \$5 billion a day, ASX becomes one of the most active securities exchanges in the world, comparable to the New York Stock Exchange and London Stock Exchanges. Market capitalization of all listed companies and the total value traded stock as percentage of GDP in Australian in the period of 1988-2012 is presented in Figure 2. Compared to Canadian context, those figures in Australia followed a relatively similar trend but witnessed the more striking values. In addition, the stock traded turnover ratio of two stock markets was illustrated in Figure 3 with the ratio of Canada outperform that in Australia from 1998-2000 before the opposite trend was seen in the rest of research period. In brief, Toronto stock exchanges and Australian stock exchanges are two of the best performers in the word over the last century thanks to its higher returns and lower volatility. The two stock markets witness the relatively similar trend in market capitalization, total value of traded stocks and stock turnover ratio with these figures in Australia slightly higher than that in Canada.

A few researches had been conducted in an effort to examine the causality relationship between stock market development and economic growth in Canada and Australia. Ross Levine (1996), in his study of 38 countries including both industrial and developing countries in the period of 1976-1993, proved that GDP grows faster in the countries with very liquid stock markets, such as United State, Canada and Australia. Randall, Jan and Nauro (1999), by applying Granger causality test for a sample of 69 countries with varying economic conditions and levels of stock market activity from 1885 to 1997 , proved that there does not exist causality between stock market activity and future economic growth in higher income countries, including Canada and Australia. Since previous research mostly based on the annual data which may not fully reflect the movement of stock market indicators as well as the economic growth, the robustness of their findings is in doubt. This paper, based on the quarterly time series data for the period of 1981 Q3 to 2012 Q3, will provide a deeper investigation to the causality between stock market development and economic growth in Canada and Australia.

\section{Methodology and Data}

\subsection{Methodology}

Testing causality among variables is one of the most crucial and, yet, one of the most challenging issues in economics (Jin-Lung Lin, 2008). This study employs Granger causality test suggested by Granger (1969) for examining the causality between stock market development and economic growth. Granger (1969) proposed a time-series data based approach in order to determine causality. Granger causality test is employed as the main approach in this paper as it provides a powerful test to investigate the causality in varied types of situation.

In this paper, Granger causality test is employed to test whether stock market "Granger-cause" economic growth and vice versa. According to Granger (1969), X causes $Y$ if the past values of $X$ could provide a better estimation of $\mathrm{Y}$ than simply using the past value of $\mathrm{Y}$. In other words, if past value of $\mathrm{X}$ statistically improve the estimation of Y, we can conclude that X Granger-cause Y (Boubakari \& Jin, 2010).

The null hypothesis is:

Ho: Stock market does not Granger-cause economic growth

The hypothesis is tested by the following equations: 


$$
\begin{gathered}
(E G)_{t}=\alpha+\sum_{i=1}^{m} \beta_{i}(E G)_{t-i}+\sum_{j=1}^{n} \gamma_{j}(S M)_{t-j}+\varepsilon_{t} \\
(S M)_{t}=\theta+\sum_{i=1}^{p} \varphi_{i}(E G)_{t-i}+\sum_{j=1}^{q} \delta_{j}(E G)_{t-j}+\tau_{t}
\end{gathered}
$$

where EG stand for economic growth proxies by Real Gross Domestic Product (RGDP) and Foreign Direct Investment (FDI); and SM is stock market proxies by Market Capitalization (MC).

The first step in empirical analysis concerns the stationarity of the EG and SM series. Granger causality test requires that the series have to be covariance stationary. For this, Augmented Dickey Fuller (ADF) test has been performed. ADF is a classic choice in literature and very strong test again unit root (Pasquale, 2006). For all of series the null hypothesis Ho of non stationary can be rejected at $5 \%$ confidence level. We expect the results to be I (0), meaning that stationary in a level.

In the second step, since Granger causality test is very sensitive to number of lags included in the regression, Akaike Information Criterion (AIC) and Schwars Information Criteria (SIC) should be employed to find an appropriate number of lags. After two requirements have been satisfied, to test the hypothesis, the restricted $\mathrm{F}$ test is applied and the statistic is defined as:

$$
F=\frac{\left[\frac{\left(S S R_{r}-S S R_{u}\right.}{n}\right]}{\left[\frac{S S R_{u}}{T-(m+n+l)}\right]}
$$

where SSRR and SSRU are the two sum of squared residual related to restricted and unrestricted form of the equation. $\mathrm{T}$ is number of observation and forms the degree of freedom; $\mathrm{n}$ and $\mathrm{m}$ are number of lags in equation (1).

\subsection{Data}

To investigate the causality between stock market development and economic growth, Real GDP and FDI are used as two proxies for economic growth. The rationales are that GDP, despite its shortcomings, remains a useful measure of human well-being; whereas, the growth is usually calculated in real terms that eliminate the distorting effect of inflation. In addition, FDI is regarded as a major source of economic growth (Afza \& Nazir, 2007). The common argue in support of FDI as a good proxy for economy growth is that FDI eases the transfer of technology, organizational and managerial practices, and, more importantly, access to international market in order to boost the growth (Mian, Muhammad, \& Usman, 2008).

Market capitalization of all listed companies in the stock market is employed as a proxy for stock market. There are two reasons for choosing market capitalization as a proxy of stock market development rather than other measures of stock market, such as, stock turnover ratio or market liquidity. First, since stock are traded in capital market, capitalization is regarded as a useful measure of public opinion of a company's net worth; total capitalization of the stock markets as a whole provides a precise snapshot of the stock market and can be compared to such economic indicators as GDP and FDI. Second and finally, to observe changes in GDP and FDI over time, it is reasonable that quarterly data rather than annual one should be taken into consideration. A quarterly frequency of market capitalization could be easily collected and recalculated from the public sources of information; whereas, quarterly data of stock turnover and stock liquidity in investigated period are not fully available.

Table 1 . Summary statistic of study variables

\begin{tabular}{lcccccc}
\hline & \multicolumn{2}{c}{ Market Cap } & \multicolumn{2}{c}{ RGDP } & \multicolumn{2}{c}{ FDI } \\
& Canada & Australia & Canada & Australia & Canada & Australia \\
\hline Mean & $5.93 \mathrm{E}+11$ & $5.11 \mathrm{E}+11$ & $2.99 \mathrm{E}+11$ & $2.36 \mathrm{E}+11$ & $6.32 \mathrm{E}+09$ & $5.52 \mathrm{E}+09$ \\
Median & $2.91 \mathrm{E}+11$ & $2.64 \mathrm{E}+11$ & $2.82 \mathrm{E}+11$ & $2.21 \mathrm{E}+11$ & $3.08 \mathrm{E}+09$ & $4.08 \mathrm{E}+09$ \\
Maximum & $2.13 \mathrm{E}+12$ & $1.61 \mathrm{E}+12$ & $4.16 \mathrm{E}+11$ & $3.70 \mathrm{E}+11$ & $5.07 \mathrm{E}+10$ & $5.39 \mathrm{E}+10$ \\
Minimum & $2.18 \mathrm{E}+10$ & $1.26 \mathrm{E}+10$ & $1.90 \mathrm{E}+11$ & $1.35 \mathrm{E}+11$ & $-8.17 \mathrm{E}+09$ & $-7.62 \mathrm{E}+10$ \\
Std. Dev. & $6.35 \mathrm{E}+11$ & $5.11 \mathrm{E}+11$ & $7.02 \mathrm{E}+10$ & $7.08 \mathrm{E}+10$ & $8.94 \mathrm{E}+09$ & $1.05 \mathrm{E}+10$ \\
Skewness & 1.013032 & 0.746569 & 0.171666 & 0.298324 & 2.412176 & -2.374931 \\
Kurtosis & 2.675105 & 2.095852 & 1.629368 & 1.792646 & 10.91293 & 35.14099 \\
Jarque-Bera & 21.92967 & 15.86951 & 10.39849 & 9.446323 & 447.3378 & 5497.939 \\
Probability & 0.000017 & 0.000358 & 0.005521 & 0.008887 & 0.000000 & 0.000000 \\
Sum & $7.41 \mathrm{E}+13$ & $6.38 \mathrm{E}+13$ & $3.73 \mathrm{E}+13$ & $2.95 \mathrm{E}+13$ & $7.90 \mathrm{E}+11$ & $6.90 \mathrm{E}+11$ \\
Sum Sq. Dev. & $5.00 \mathrm{E}+25$ & $3.23 \mathrm{E}+25$ & $6.12 \mathrm{E}+23$ & $6.21 \mathrm{E}+23$ & $9.90 \mathrm{E}+21$ & $1.37 \mathrm{E}+22$ \\
Observations & 125 & 125 & 125 & 125 & 125 & 125 \\
\hline
\end{tabular}

Source: Datastream and Canadian Socioeconomic Information Management. 
All data analyzed in this paper are taken from Datastream Thomson Reuter [DS] and Canadian Socioeconomic Information Management website [CANSIM] with quarterly frequency. Particularly, in Canadian, quarterly market capitalization of 1566 listed companies in Toronto stock exchange (1981 Quarter 3 to 2012 Quarter 3) is collected, then, employed to calculate the market capitalization of the whole stock market in the investigated period. The same method is applied to Australian market with quarterly market capitalization of 1955 listed companies in Australian stock exchange (ASX) used to calculate market capitalization of ASX from 1981Q3 to 2012Q3. Beside, quarterly Real GDP and FDI of two research markets are extracted from DS and then compared to that of CANSIM. Summary of statistic of study variables is provided in Table 1.

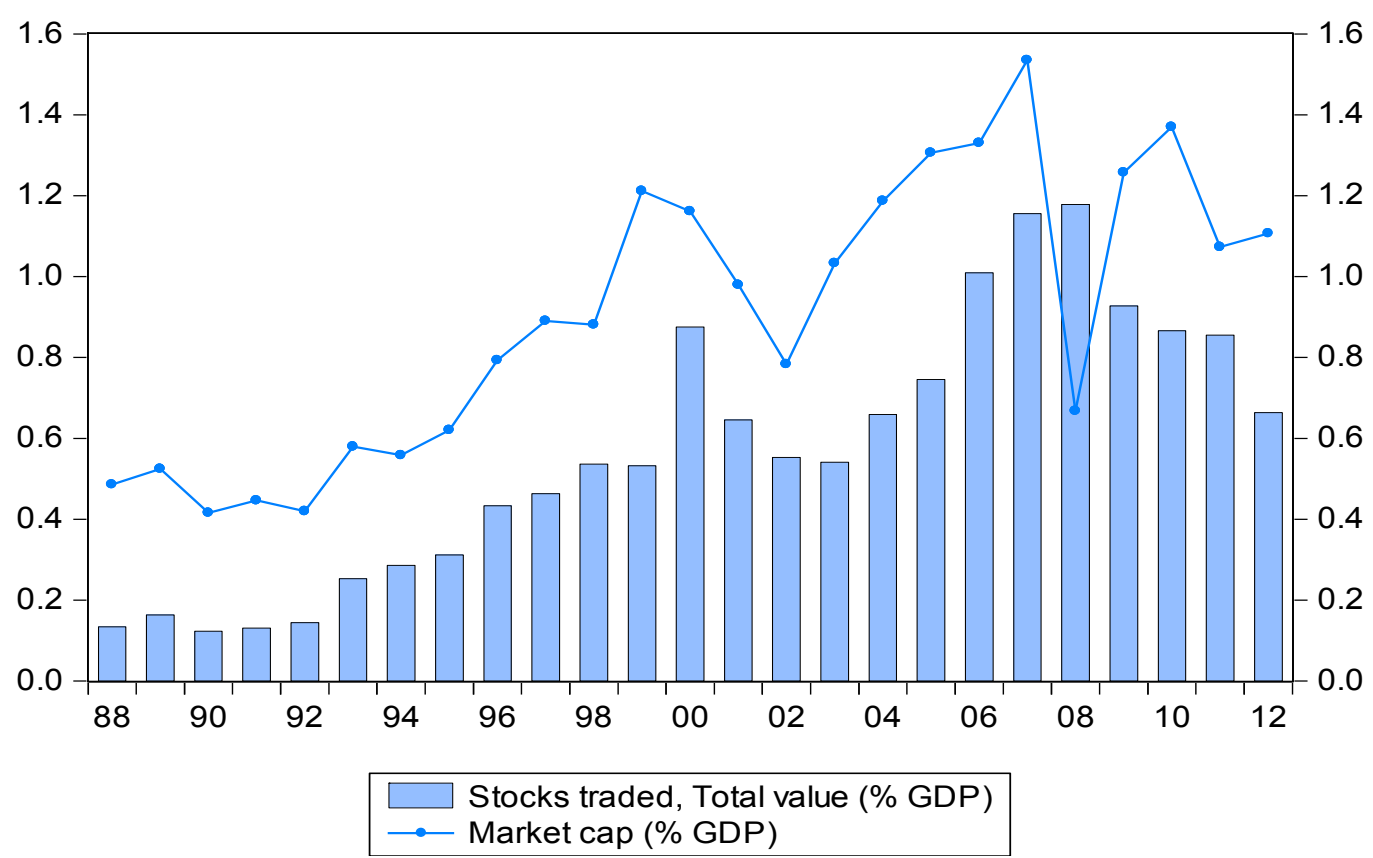

Figure 1. Market capitalization of listed companies and value of traded stock in Canada

Source: World Bank Indicator, Standard \& Poor's and Global Stock Markets Factbook.

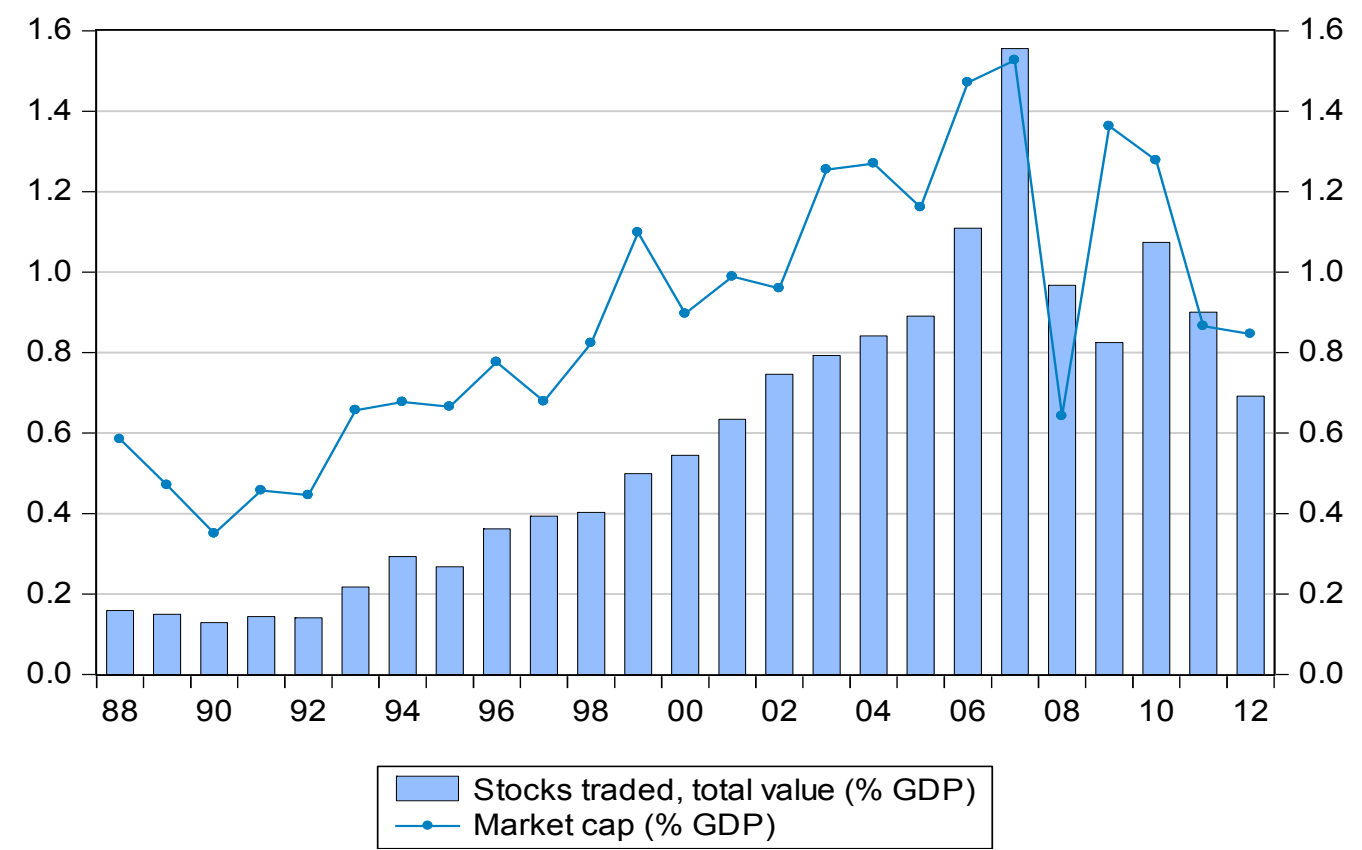

Figure 2. Market capitalization of listed companies and value of traded stock in Australia

Source: World Bank Indicator, Standard \& Poor's and Global Stock Markets Factbook. 


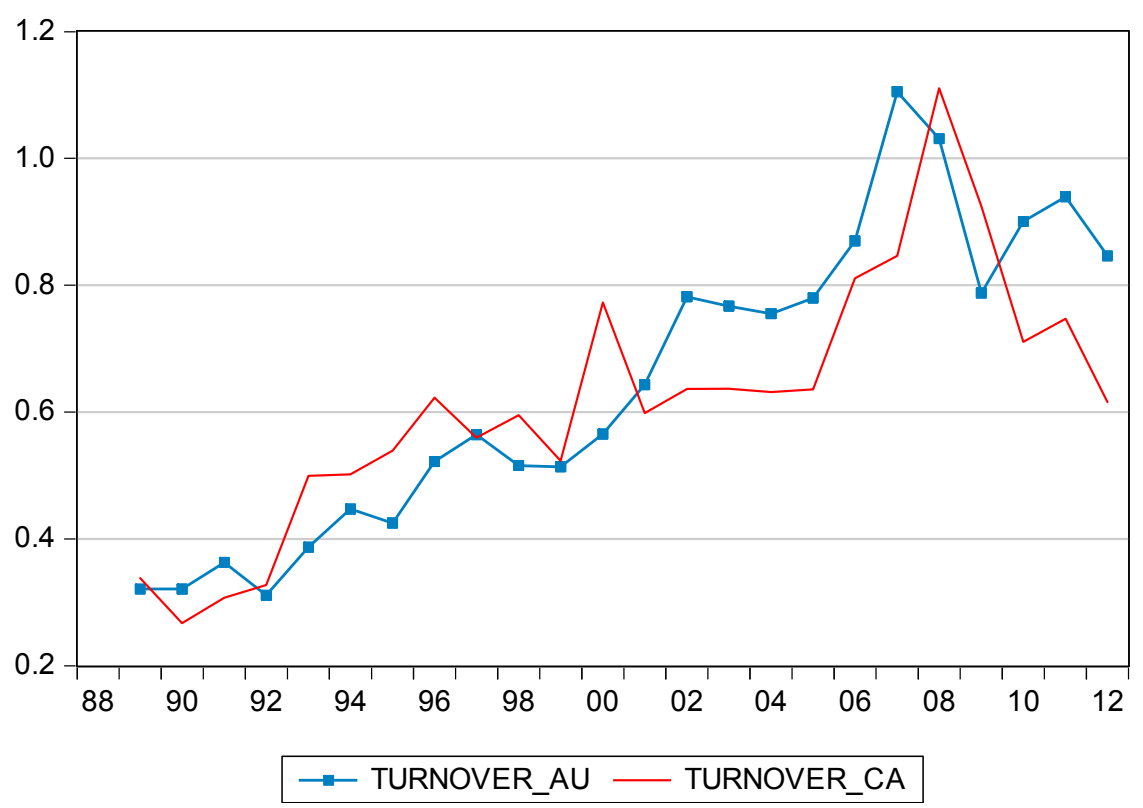

Figure 3. Stocks traded, turnover ratio (\%) in Canada and Australia

Source: World Bank Indicator, Standard \& Poor's and Global Stock Markets Factbook.

\begin{tabular}{llll}
\hline & MV_CA & RGDP_CA & FDI_CA \\
\hline MV_CA & 1 & 0.931445 & 0.524497 \\
RGDP_CA & 0.931445 & 1 & 0.531476 \\
FDI_CA & 0.524497 & 0.531476 & 1 \\
\hline
\end{tabular}
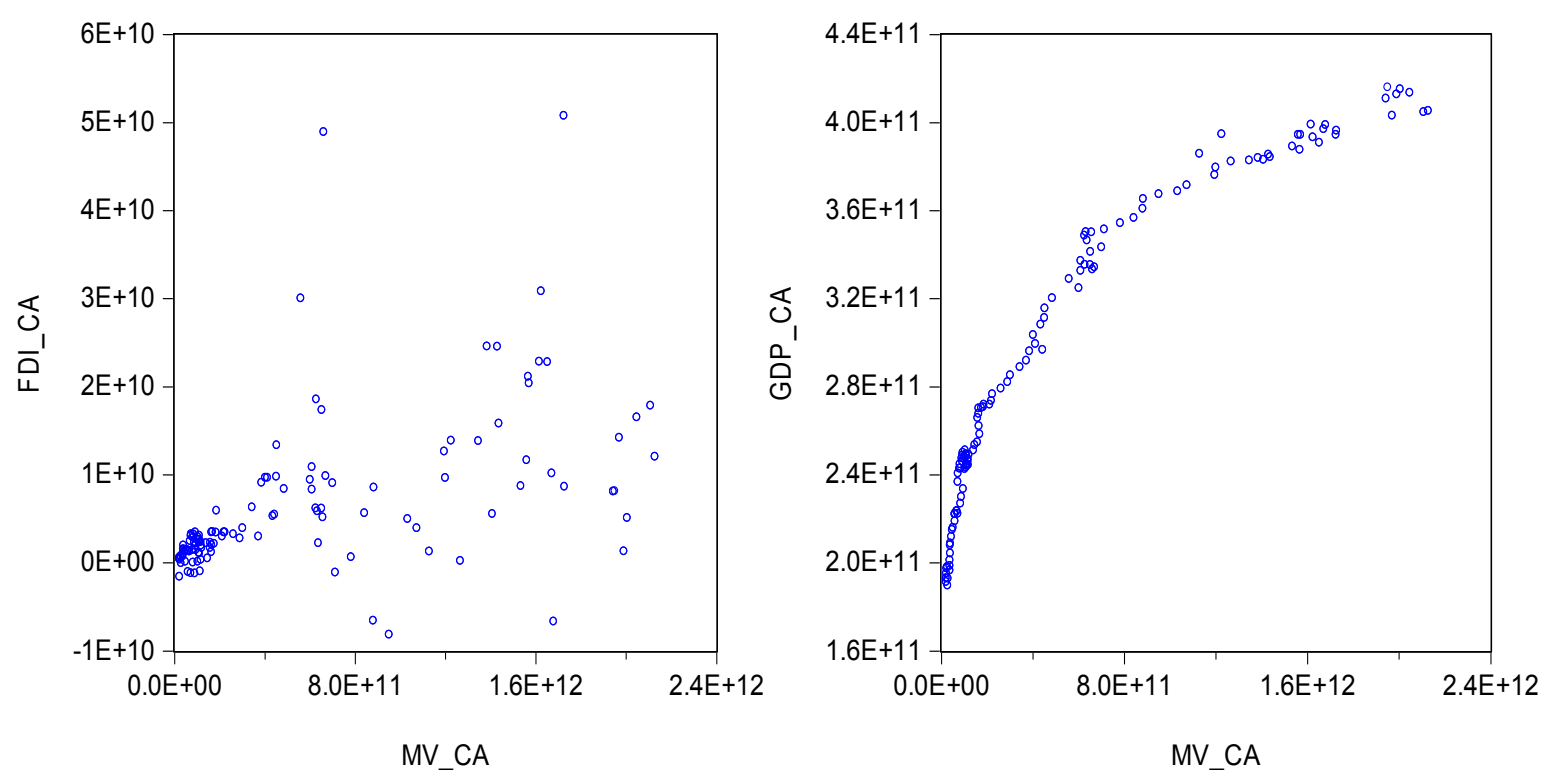

Figure 4. Correlation between study variables in Canada 


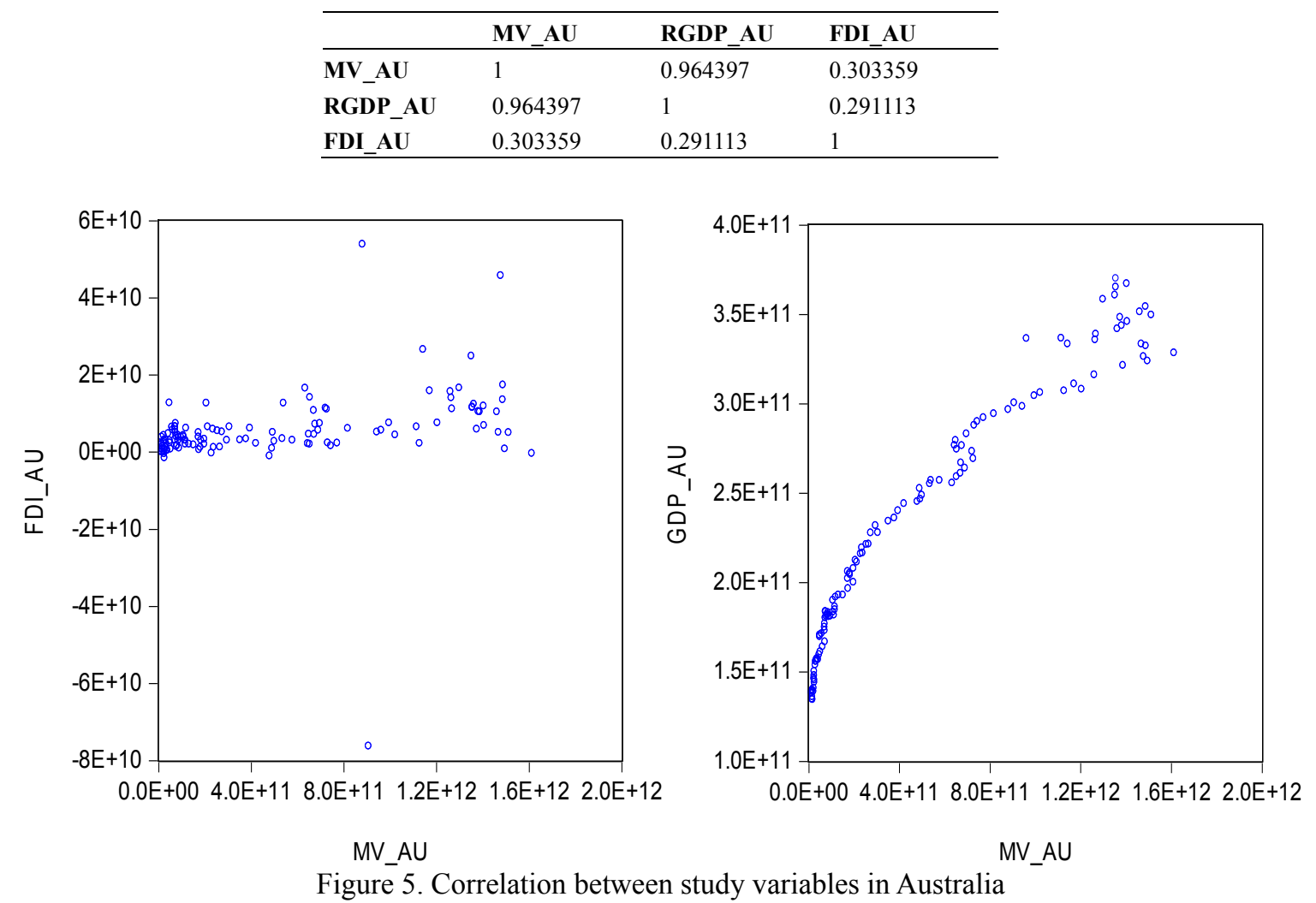

\section{Empirical Analysis and Result}

The first step in empirical analysis concerns the stationarity of the EG and SM series. For this, Augmented Dickey Fuller (ADF) test has been performed. The result of ADF test for unit root presented in Table 2 indicates that for all series the null hypotheses are rejected at $5 \%$ confidence level. The results reflects that study variables are either I (0), that is stationary in level or I (1), that is stationary at the first level of difference.

Since the series are stationary, Akaike Information Criterion (AIC) and Schwars Information Criteria (SIC) are employed to find an appropriate number of lags. It is worth emphasizing that Granger causality test is very sensitive to number of lags included in the regression and that AIC and SIC are the two most common criterions employed in many previous research. According to AIC and SIC, the optimal lag of 3 is applied for study variables.

The results of Granger causality test are presented in Table 3 and 4. The results suggest Granger causality relationship between stock market proxies (Market cap) and economic growth proxies (Real GDP and FDI) in Canada. Surprisingly, both null hypotheses in favor of Canadian context can be rejected at $1 \%$ level of significance. Thus, the results in Table 3 indicates that the stock market development significantly "Granger cause" economic growth in Canada. When it comes to Australian context, no strong evidences for the causality relationship are captured. According to results of Table 4, the null hypotheses that stock market "Granger cause" Real GDP in Australia is not rejected at $5 \%$ of significance. However, the null hypothesis that stock market "Granger cause" FDI can be rejected at $1 \%$ of significance. Interestingly, even the stock market development is proved not to boost the Real GDP, it does stimulate the FDI. Thus, no significant evidences about the causality relationship between stock market development and economic growth are captured in Australia.

The findings raise an interesting question about the context in Australia and Canada. Even though the two markets are expected to be relatively similar in term of both capital market development and market stability, different results in causality between stock market development and economic growth are seen in these markets. In particular, Granger causality test supports the causality between stock market development and economic growth in Canada for the period of 1981 Q3 to 2012 Q3. This is consistent with the findings of Ross Levine (1996) that GDP grows faster in the countries with very liquid stock market, yet, provides a strong argument to the results of Randall, Jan and Nauro (1999) that no causality between stock market activity and future economic growth exists in higher income countries. When it comes to Australian context, no significant causality between stock market development and economic growth was seen, even, market capitalization is proved to boost the 
growth in FDI. Supporters in favour of causality between stock market development and FDI argue that the developed and liquid financial stock markets provides a better source of information and capital allocation for market participants, and, thus, help enhance the soundness and transparency in capital markets that ultimately stimulate the foreign investments.

Furthermore, correlations between study variables in two markets are presented in Figure 4 and Figure 5 in an effort to explain the findings in Australia. The figures indicate that the correlations between economic growth (proxies by Real GDP) and stock market development (proxies by Market cap) in Australia are relatively stronger than that in Canada. It could be explained that the rise in stock market tends to significantly boost the economic growth in Australia, but in case of financial crisis, a negative impact of stock market downturn on national economy seems to be worse in Australia than that in Canada. In other words, it takes longer time for the Australian economy to fully recover and then continue a growth from a recession than Canadian market. In addition, the huge supports from government policies and close cooperation between equity market and banking systems during recession significantly motivated the prompt recovery of financial markets and economic growth in Canada. The huge impacts of the financial crisis and the global recession in 2008-2009, therefore, could be a reasonable explanation for the differences discovered in two investigated markets. It also suggests a new chapter for further research that investigates the causality between stock market development and economic growth in the period before and after the global recession.

Table 2A. ADF test results for stationary

\begin{tabular}{llllll}
\hline $\begin{array}{l}\text { Australia } \\
\text { Variable }\end{array}$ & Obs & ADF Test & Variable & ADF Test & Decision \\
\hline MV & 125 & -2.197220 & DMV & -6.866354 & $\mathrm{I}(1)$ \\
RGDP & 125 & 3.495305 & DRGDP & & $\mathrm{I}(0)$ \\
FDI & 125 & -10.51628 & DFDI & & $\mathrm{I}(0)$ \\
\hline
\end{tabular}

Critical values are $1 \%-3.483751,5 \%-2.884856$ and $10 \%-2.579282$.

Table 2B. ADF test results for stationary

\begin{tabular}{lllllr}
\hline $\begin{array}{l}\text { Canada } \\
\text { Variable }\end{array}$ & Obs & ADF Test & Variable & ADF Test & Decision \\
\hline MV & 125 & -1.031365 & DMV & -8.896289 & I $(1)$ \\
RGDP & 125 & 0.053059 & DRGDP & -5.929786 & $\mathrm{I}(1)$ \\
FDI & 125 & -3.488652 & DFDI & & $\mathrm{I}(0)$ \\
\hline
\end{tabular}

Critical values are $1 \%-3.484198,5 \%-2.885051$ and $10 \%-2.579386$.

Table 3. Pairwise granger causality tests in Canada

\begin{tabular}{llllll}
\hline Null Hypothesis: & Obs & Lag & F-Statistic & Prob. & Causality \\
\hline RGDP does not Granger Cause MV & 122 & 3 & 2.25018 & 0.0863 & No \\
MV does not Granger Cause RGDP & & & 4.92825 & $0.0029^{* *}$ & Yes \\
FDI does not Granger Cause MV & 122 & 3 & 1.95430 & 0.1248 & No \\
MV does not Granger Cause FDI & & & 7.13855 & $0.0002^{* *}$ & Yes \\
\hline
\end{tabular}

** show that null hypothesis is rejected at $1 \%$ level of significance.

Table 4. Pairwise granger causality tests in Australia

\begin{tabular}{llllll}
\hline Null Hypothesis: & Obs & Lag & F-Statistic & Prob. & Causality \\
\hline RGDP does not Granger Cause MV & 122 & 3 & 4.51989 & 0.0049 & Yes \\
MV does not Granger Cause RGDP & & & 0.96339 & $0.4126^{*}$ & No \\
FDI does not Granger Cause MV & 122 & 3 & 0.44533 & 0.7211 & No \\
MV does not Granger Cause FDI & & & 6.00739 & $0.0008^{* *}$ & Yes \\
\hline
\end{tabular}

* show that null hypothesis is not rejected at $5 \%$ level of significance.

** show that null hypothesis is rejected at $1 \%$ level of significance. 


\section{Conclusion}

The paper studies the causality relationship between stock market development and economic growth in Canada and Australia based on the time series data for the period of 1981 Q3 to 2012 Q3. The results of Granger test suggest the causality between stock market development and economic growth in Canada but it is not the case in Australia. It reveals that stock market and economic growth has long-run relationship and that the stock market development does help improve the future growth in some developed countries. This is consistent with the findings of Ross Levine (1996), yet provides a strong argument to the results of Randall, Jan and Nauro (1999). The results also cast doubt on the results of Ake Boubakari and Dehuan Jin (2010) by providing the evidence from Australia-one of the best performers in world's stock market over the last century-to argue that for developed countries with significantly active and highly liquid stock market, the causality between stock market development and economic growth may not exist. Since financial crisis and recession significantly influences to global economies, the study suggests a new chapter for future research that will investigate the causality between stock market development and economic growth in the period before and after the global recession. The causality employed in this study is Granger causality. This study suggests that future research should combine Granger causality and other causalities to dig up deeper the relationship between stock market development and economic growth in other developed countries.

\section{Acknowledgments}

We are grateful to Russell Gregory-Allen, Linh Nguyen and conference participants at Massey University, The 17th Annual Waikato Management School Student Research Conference 2013, University of Waikato, New Zealand, The 43rd Annual Atlantic Schools of Business Conference, St. Francis Xavier University, Canada and National Economics University of Vietnam for their generous comments. We thank Hanh Thi Phan and Nguyen Lan Anh for their research assistances.

\section{References}

Afza, \& Nazir. (2007). Economic competitiveness and human resource development: An FDI perspective. Pakistan Economic and Social Review, 45(2), 167-180.

Ake, B., \& Dehuan, J. (2010). The role of stock market development in economic growth: Evidence from some Euronext countries. International Journal of Financial Research, 1(1), 14-20.

Atje, R., \& Jovanovic, B. (1993). Stock markets and development. European Economic Review, 37(2-3), 632640. http://dx.doi.org/10.1016/0014-2921(93)90053-D

Beck, T., \& Levine, R. (2003). Stock markets, banks, and growth: Panel evidence. Journal of Banking and Finance, 28(3), 423-442. http://dx.doi.org/10.1016/S0378-4266(02)00408-9

Campbell, R. H. (1989). Forecast of Economic growth from the bond and stock market. Financial Analysis Journal, 38-45.

Caporale, G. M., Howells, P. G., \& Soliman, A. M. (2004). Stock market development and economic growth: A casual linkage. Journal of Economic Development, (29), 33-50.

Choong, K. C., Yusop, Z., Law, H. S., \& Khim, L. V. (1996). Financial development and economic growth in Malaysia: The stock market perspective. Investment Management and Financial Innovations, (4), 105-115.

Granger, C. J. (1969). Investigating causal relationships by econometrics models and cross spectral methods. Econometrica, (37), 424-435. http://dx.doi.org/10.2307/1912791

Greenwood, J., \& Jovanovic, B. (1990). Financial development, growth and the distribution of income. Journal of Political Economy, 98(5), 1076-1107. http://dx.doi.org/10.1086/261720

Greenwood, J., \& Smith, B. (1994). Financial markets in development and the development of financial market. Journal of Economic Dynamics and Control, 21(1), 145-181. http://dx.doi.org/10.1016/0165-1889(95)00928-0

King, R., \& Levine, R. (1993a). Finance and Growth: Schumpeter Might Be Right. Quarterly Journal of Economics, 108(3), 717-737. http://dx.doi.org/10.2307/2118406

Levine, R. (1991). Stock market growth and tax policy. Journal of Finance, (46), 1445-1465. http://dx.doi.org/10.1111/j.1540-6261.1991.tb04625.x

Levine, R. (1996). Stock Markets: A Spur to Economic Growth. Finance \& Development, 7-10.

Levine, R., \& Zervos, S. (1996a). Stock market development and long-run growth. The World Bank, Policy 
research working paper \# 1582.

Levine, R., \& Zervos, S. (1998). Stock Market, Banks and Economic Growth. American Economic Review, 88(3), $537-558$.

Lin, J. L. (2008). Notes on Testing Causality (pp. 1-18). Institute of Economics, National Chengchi University.

Mansor, H. I. (2011). Stock Market Development and Macroeconomic Performance in Thailand. Inzinerine Ekonomika-Engineering Economics, 22(3), 230-240.

Mauro, P. (2000). Stock returns and output growth in emerging and advanced economies. IMF Working Paper \# 89. http://dx.doi.org/10.5089/9781451851274.001

Mian, S. N., Muhammad, M. N., \& Usman, J. G. (2010). Relationship between economic growth and stock market development. African Journal of Business Management, 4(16), 3473-3479.

Mirakhor, S., \& Lillanueva, R. M. (1990). Market Integration and Investment Barriers in Emerging Equity Markets. World Bank Discussion Paper \# 216: 221-255.

Neusser, K., \& Maurice, K. (1998). Manufacturing Growth and Financial Development: Evidence from OECD Countries. Review of Economics and Statistics, (80), 638-646. http://dx.doi.org/10.1162/003465398557726

Obstfeld, M. (1994b). Risk-Taking, Global Diversification, and Growth. American Economic Review, 84(5), $1310-1329$.

Pasquale, F. (2006). Testing for Granger causality between stock prices and economic growth. Munich Personal RePEc Archive \# 2962: 1-1.

Pearce, D. K. (1983). Stock prices and the economy. Federal Reserve Bank of Kansas City Economic Review, 712.

Randall, K. F., Jan, H., \& Nauro, F. C. (1999). Do Stock Markets Promote Economic Growth. Working Paper \# 267: $1-2$.

Rousseau, P. L., \& Wachtel, P. (2000). Equity markets and growth: Cross country evidence on timing and outcomes. Journal of Banking and Finance, (24), 1933-1957. http://dx.doi.org/10.1016/S0378-4266(99)00123-5

Stiglitz, J. E., \& Weiss, A. (1981). Credit rationing in markets with imperfect information. American Economic Review, (71), 393-410.

Thornton, J. (1995). Financial Deepening and Economic Growth in Developing Countries. Economia Internazionale, 48(3), 423-430.

Wong, A., \& Zhou, X. (2011). Development of Financial Market and Economic Growth: Review of Hong Kong, China, Japan, The United States and The United Kingdom. International Journal of Economics and Finance, 3(2), 111-115. http://dx.doi.org/10.5539/ijef.v3n2p111

\section{Copyrights}

Copyright for this article is retained by the author(s), with first publication rights granted to the journal.

This is an open-access article distributed under the terms and conditions of the Creative Commons Attribution license (http://creativecommons.org/licenses/by/3.0/). 